\title{
GRADITI DOSTOJANSTVO IN TKATI DRUŽBENE VEZI
}

\section{Graditi dostojanstvo in tkati družbene vezi}

Ministrstvo za delo, družino in socialne zadeve pripravlja za čas predsedovanja Slovenije Evropski uniji konferenco na temo novih oblik solidarnosti med rodovi in novih oblik za vzpostavljanje solidarnosti - te starodavne družbene vezi. Solidarnost namreč zagotavlja, da se tisto, kar imamo, preteče $k$ onim, ki tega nimajo. To je lahko marsikaj, tudi znanje in kultura. ${ }^{l}$ Brez solidarnosti se prekinejo vezi med preteklimi rodovi in tistimi, ki šele prihajajo.

Sredi prerazporejanja bogastva in družbene moči se zdijo mnogi vse bolj odrinjeni na družbeni rob. In tako se veča neenakost: med spoloma, med starostnimi skupinami, po gmotnem položaju, zapostavljenost $v$ urbanem prostoru, neenakost po udeležbi $v$ kulturi in izobraževanju. Težko je tedaj pričakovati, da se bodo tisti na družbenem robu dobro vključili v družbeni in gospodarski razvoj, kar seveda prizadene vso družbo. Odtod skrb za izobraževanje »ranljivih skupin« in družbeno trdnost, ki naj bi jo v Evropi na različne načine, tudi s pomočjo izobraževanja, dosegli.

Če je vrst neenakosti tako veliko, tedaj ni nenavadno, da na vrata naše države trka tudi njena skrajna posledica: revščina. Ali je »absolutna« ali »relativna«, ni pomembno. Pomembno je, da se tega pojava zavemo, da vemo, da ga gospodarska rast, za katero si prizadevamo, ne bo odpravila, kajti pojav ni posledica enega, marveč vrste dejavnikov. ${ }^{2} \check{C}$ e pristanemo na izključenost revnih iz družbe,
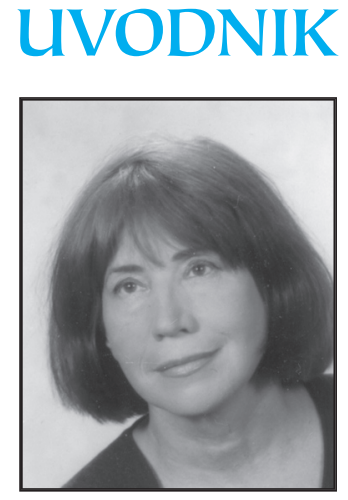

Doc. dr. Dušana

Findeisen s tem pristajamo na lahko »rešitev《 tega vprašanja, tj. podpiranje revnih, vzdrževanje revnih v odvisnosti.

Pomembnoje torej, da o revščini razmišljamo, jo preprečujemo in odpravljamo, vsi, ne le država. Da si vsi skupaj prizadevamo za to, da se revni vključijo v družbo, da znova stkemo razvezane družbene vezi. Če želimo vključiti $v$ družbo čim večje število revnih, je pomembno, da se sleherni župan, sleherni občinski svetnik, sleherni predsednik tega ali onega društva, sleherni socialni delavec, sleherni državni uradnik, sleherni direktor podjetja zavzame proti revščini. Iz dolge vrste za to »zadolženih» izobraževalci odraslih nismo izključeni, nasprotno!

\section{Ali poznamo in razumemo revne?}

Na revne ljudi se lepi vrsta slabšalnih stereotipov; da so neizobraženi, leni, da imajo raje socialno pomoč, kakor da bi delali. $\mathrm{Pa}$ smo se sploh vprašali, kdo so revni? Revni namreč niso zgolj nezaposleni, tisti, ki prejemajo socialno pomoč, ali zgolj tisti, ki so na družbenem robu, ali morebiti tisti, ki so »vzdrževani« kot denimo invalidi in mnogi upokojenci. Revni so danes celo zaposleni! Kajti kupna moč pada in mnogi se mučijo za nizko plačilo, potem pa končajo živčno, telesno, čustveno izčrpani. Končajo kot žrtve nesreč na delu in sodobnih poklicnih bolezni. Revni so lahko oni, ki zaradi preobilice začasnih del ne zmorejo ali tudi ne znajo življenja organizirati okrog dela za nedoločen čas. Revni vse dlje potujejo na delo, vse slabše stanujejo, vse bolj so 
kulturno osiromašeni, vse manj so deležni izobraževanja. Njihovim otrokom se svet in prihodnost zapirata. Osiromašenje ali pauperizacija (izposojenka se zdi manj grozeča!) ne prizadene le gmotnega stanja revnih, marveč vse njihovo življenje. Je razčlovečenje in je odtujitev človeka. ${ }^{3}$

In vendar imamo vsi pravico, da smo koristni, da smo vpleteni $v$ izmenjave, ki potekajo med družbenimi člani, revščina ali blagostanje pa sta hkrati vprašanje vse družbe in vprašanje države. Naloga te je, da sprejme zakone, $k i$ naj omogočijo novo vrsto družbene pogodbe utemeljene na etiki družbenih odnosov. Gre za to, da se kolektivno zavemo, da naša družba ne funkcionira, kot bi morala, da zgolj država blaginje ne more kaj dosti proti »novi revščini«. Različne vrste socialne pomoči tako niso dovolj. Potrebujemo nove oblike solidarnosti. Gre za to, da poiščemo načine, kako okrepiti trdnost in povezanost družbe.

Število revnih se povečuje zaradi strukturnih sprememb, ki vplivajo na nezaposlenost in družbeno izločenost: »razpad« trga dela, povečanje števila obrobnih del in oblik zaposlitve, težje vključevanje mladih na trg dela, šibkost in ranljivost družinskih vezi, kar vse slabi primarne oblike solidarnosti. Tako je vse več onih, ki potrebujejo družbeno pomoč. Med njimi se zdijo naslednje tri skupine najvidnejše: ranljivi, ki potrebujejo pomoč občasno, morda zato, ker so se začasno znašli brez zaposlitve. Negotovost dohodkov namreč naredi, da zgolj občasno sodelujejo $v$ ekonomskem in družbenem življenju. Sem se uvrščajo tudi zaposleni, ki jim plačilo ne zadostuje za dostojno življenje, podpirani, ki dolgotrajno prejemajo pogodbeno dogovorjeno pomoč. Največkrat že več let ne delajo zaradi telesne, psihične ali moralne prizadetosti ali prejemajo podporo zaradi nezmožnosti, da bi pomagali svojim otrokom. Marginalizirani, ki stanujejo slabo ali so na cesti, niso veliko delali in prejemali socialne pomoči. V to skupino značilno sodijo brezdomci.

Kadar je vrednost nekoga na trgu dela nizka, zato ker je denimo starejši ali bolan, se mu porušijo tudi družbene vezi: manj ima stikov $z$ drugimi, kar načne identiteto, poveča se osamljenost, obrnjenost vase. Pride do izgube pravice do javnega življenja, življenja zunaj doma. Nekateri se znajdejo med revnimi zato, ker se ne morejo podrediti normam in pričakovanjem sodobnega sveta. Tudi njihove družbene vezi se močno zrahljajo. Za takšne skupine imajo, denimo na Finskem, mrežo centrov, ki jim pomagajo pri vključevanju na trg dela. To niso neke brezdušne ustanove, marveč so $v$ njih ekipe strokovnjakov, ki takšnim, iz dela izvrženim ljudem, stojijo ob strani. Revni so tudi mnogi, ki niso znali presoditi, da se zadolžujejo preveč. Ker so nekdanje omejitve glede višine zadolževanja poniknile, so podlegli prepričevanju bank in trgovcev ter si naprtili kredite, ki jih ne zmorejo odplačati. Kako se znajti sredi prevelike zadolženosti brez znanja in pomoči svetovalcev? V mnogih evropskih državah se $z$ njimi ukvarjajo ekipe strokovnjakov. Niso na milost in nemilost prepuščeni bančnim izterjevalcem. Revni pa so največkrat tisti, ki so funkcionalno nepismeni, ne uporabljajo pisnih virov $v$ vsakdanjem življenju, si ne znajo razložiti, kaj se jim dogaja, saj posameznih vprašanj ne znajo umestiti $v$ širši okvir. Tisti, ki ne znajo zagledati povezav med vzrokom in posledico, ne znajo dobro sklepati, ki se zaradi premalo znanja ali drugih težav ne morejo prilagoditi na spremembe; tisti, ki zaradi sramu in čustvenih težav niso učljivi. Zato so podrejeni naključjem in muham onih, ki so bolj izobraženi in bolj pismeni, ali onim, ki imajo oblast nad njimi.

Za izobraževanje odraslih je značilno, da se odziva na individualne in družbene potrebe, $v$ veliki meri pa potrebe tudi napoveduje in 
nas nanje pripravlja. Dovolj je, če se ozremo naokrog, če poznamo reforme, ki so že izvedene, ali one, ki se pripravljajo, sprva $v$ Evropski uniji ter kasneje tudi pri nas, in že zaznamo vrsto problemov, ki jih je moč »prevesti« $v$ izobraževalne programe: potrebujemo izobraževanje starejših delavcev, delodajalcev in osveščanje javnosti o tem, da se skupno število zaposlenih manjša, da želimo zadržati stabilnost javnih financ in preprečiti revščino starih; o tem torej, da je potrebno poskrbeti, da starejši ostanejo dlje na delovnem mestu; v boljših delovnih okoliščinah in z več izobraževanja potrebujemo izobraževanje upokojenih za vrnitev na trg dela in za prostovoljno vključevanje $\mathrm{v}$ družbeni razvoj, izobraževanje za funkcionalno pismenost, ki ne more biti vprašanje zgolj posameznih ustanov, marveč vseh nas, izobraževanje za večanje splošne usposobljenosti, ki poveča vse druge zmožnosti, izobraževanje za finančno stabilnost, za vodenje družinskega proračuna, izobraževanje za dejavne potrošnike ... izobraževanje za funkcionalne družinske odnose, potrebujemo svetovanje, spremljanje ... in še bi lahko naštevali. Potreb je veliko!

Izobraževanje za preprečevanje in izkoreninjenje revščine ter za vključenost $v$ družbo je najpogosteje namenjeno usposabljanju ali preusposabljanju za delo. A potrebovali bi več programov za krepitev družbenih vezi, ki se revnim močno zrahljajo. Omogočilo naj bi, da nekdo spozna samega sebe, da dovolj dobro spozna tudi svoje okolje in si tako naredi tudi dovolj dober načrt, kako se bo iz revščine izkopal. Pri tem mora biti svoboden in naj svobodno izbira $z$ veliko vednosti in znanja. Nikogar ne smemo siliti $v$ naše »rešitve«. ${ }^{4} \check{S}$ e več, dostojanstvo si revni lahko gradijo s kulturo, mi pa jo moramo narediti zanje dostopno.
${ }^{1}$ Pedagoška fakulteta v Ljubljani se je nedavno obrnila na Slovensko univerzo za tretje življenjsko obdobje, da bi med njenimi slušatelji pridobila mentorje brezposelnim nad 50 let. V Italiji 600 upokojenih direktorjev podjetij malo izobraženim mladim utira podjetniško pot itd.

${ }^{2}$ Sere Paugam, Societe francaise et ses pauvres, PUF, Pariz, 1995; Andrien Zeller, J. O., Debats parlementaires, 4. oktober 1988, str. 652.

${ }^{3}$ Andre Barjonet, Qu'est-ce que la pauperisation? Editions sociales, Pariz, 1961.

${ }^{4}$ Zdajšnje posebne zaposlitvene pogodbe, na katerih temeljijo javna dela, zahtevajo nadzor in strogo delitev del, kakršna smo poznali v industrijskih časih. Ker pogodba v imenu zaščite delavca prepoveduje, da bi bil ta samostojen, odgovoren in ustvarjalen, trdim, da zaposljivosti, ki jo danes pričakujemo od zaposlenih, ne podpira, marveč jo, nasprotno, spodkopava in zmanjšuje! 